\title{
Analysis of and Study on Internal Control of Computerized Accounting System in Internet Environment
}

\author{
Gexin Sun \\ Heilongjiang Vocational College, Shuangcheng 150111, China
}

\begin{abstract}
With the the development of E-commerce and increasingly more and more use of computerized accounting system, the internal and external environments of corporate accounting and accounting management have changed dramatically. The internal control mechanism and means of traditional computerized accounting system may be hard to work effectively in internet environment. It is urgent for corporate to establish a new internal control system adaptable to the internet environment. This paper first analyzed the internal corporate control theoretically and the characteristics of the internal control of computerized accounting system, then analyzed in detail the components of internal control of computerized accounting system in general environment. It also pointed out in computerized accounting system that general control shall include organization control, system development and maintenance control, system security control, operation control and file control; that application control shall include input control, processing control and output control.
\end{abstract}

Keywords: Internet, Computerized Accounting, Internal Control

\section{Introduction}

Currently, the accuracy and reliability problem of accounting information has been prominent in China social and economic life. It can directly shake people's trust on accounting information, interfere with the corporate operation decisions and result in information technology cannot be applied widely in accounting field. Thus, it is urgent to make efforts to avoid accounting information distortion and ensure the accounting information quality. In 1970's, it is computerized system's infancy stage in China, since then, it has developed and stepped into a mature stage now. As anyone can see, the application of information technology, on one hand, has made accounting change a lot, however, on the other hand, it also makes it more difficult to perform internal control of accounting information system. These results in people worry about and even challenge the quality of a series of information generated in the computerized accounting system. To some extent, it has restricted the development of the computerized accounting system. Therefore, it is necessary to do research on the internal control of computerized accounting system.

\section{Theoretical Analysis of Internal Control of Computerized Accounting System}

The concept of internal control generates from internal audit. It was first proposed 
and defined in announcement for Examination of Financial Statements by Independent Public Accountants published by American Institute of Accountants. It was defined as "Internal control refers to a series of measures taken and methods applied to examine the accuracy of accounting books and records to protect the security of a corporate's cash and other assets". From this definition, obviously, we see easily see that it still covers internal audit. Afterwards, a sub-committee of audit program committee of American Institute of Accountants defined internal control authoritatively as "Internal control includes structure design of an organization and all methods applied and measures taken by a corporate for internal mutual coordination. These methods and measures are applicable to protecting corporate assets, examining the accuracy of accounting information in order to increase operation efficiency and promote the corporate to implement its existing management policies." in its released report Internal Control-Importance for Adjusting Varied Elements of an Organization and for Management Authorities and Independent Certified Public Accountants.

Internal corporate control is a series of policies and processes made and implemented to ensure the corporate carries out activities effectively and protect the security and integrity of corporate assets and etc. to prevent, discover and correct errors and irregularities so as to ensure all information and data are true, legitimate and complete. Internal control generally covers all links of corporate production and operation, including control environment, risk assessment, control decisions, information transmission and self-testing. Undoubtedly, effective implementation of internal control will promote a higher level of corporate production management and rationalization and regularization of corporate operation process.

\section{Study on Methods to Carry Out Internal Control of Computerized Accounting System in Internet Environment}

With the development of information technology and the internet, the traditional single-computer computerized accounting system and LAN computerized accounting system have been gradually replaced by the computerized accounting system based on internet technology platform. Thus, before we start to do research on the internal control of computerized accounting system in the internet environment; inevitably, we need to understand, in the internet environment, what are the basic modes and functions of computerized accounting system, as well as, in what way the system works. The computerized accounting system running in internet environment can be regarded as an accounting system runs in the internet environment and confirms measures, calculates and reports a variety of corporate operation activities. It is an accounting information system established based on internet environment, an indispensable part of internet economy and closely related to e-commerce. It can help a corporate to achieve the coordination between financial activities and business activities, remote statements, reimbursements, auditing of accounts, auditing and other remote processing, operation forecast, dynamic accounting, online financial management and management decisions. It supports electronic documents and electronic money. It changes the way to obtain, use and disclose financial information. The computerized accounting system running in internet environment is quite different 
from the traditional network version financial system. It runs in INTERNET environment and connects the LAN and the WAN.

The so-called three-tier architecture technology is to divide the $\mathrm{C} / \mathrm{S}$ (Client/Server) system into three-tier services (Client server, Application server and Database server, as shown in Figure I). The middle layer-application server is a key technology. It encapsulates application server logics and manages the connection between the clients and the database server, extremely increase internet performance and security performance.

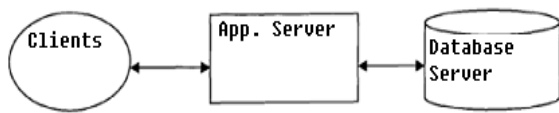

Fig. 1: Three-tier $\mathrm{C} / \mathrm{S}$ architecture

A number of internet-related technologies, including security technology, webpage technology, electronic transaction technology and etc., are collectively called Web technology. The security technology is used to protect the server data and ensure the data security during transmission. The webpage technology refers to the technology for compiling server application to generate WebPages so that users can view and operation the financial data through the browser in real time. This is a client interface processing technology. It is to meet the demands of remote users. The electronic transaction technology refers to the related technology to carry out the electronic transaction activities successfully and ensure the accuracy and confidentiality of the electronic transactions. In internet environment, the three foregoing main technologies were adopted in the computerized accounting system to not only achieve decentralized, real-time raw accounting data collection, dynamic data processing and centralized financial management but also integrate system components and achieve the internal coordination within the corporate and the coordination between the corporate and the external environment.

According to the foregoing three kinds of technologies and the characteristics of the computerized accounting system itself, based on the basic principles of business process re-engineering to redesign the processes of manual accounting system, then, the basic components of the computerized accounting system running in the internet environment can be obtained as shown in Figure 2.

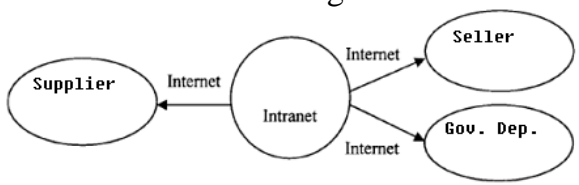

Fig. 2: Relationships between corporate and external related organizations in computerized accounting system running in internet environment

From Figure 2, it is easy for us to summarize the work processes of the computerized accounting system running in internet environment:

1) The grassroots units (such as business units or branches) transmit the raw information by certain computing methods to the head office or the host computer of the head office through internet;

2) After receiving the raw information, the host computer sends the raw data to the internet for review by related government functional departments (such as taxation departments, banks, industrial and commercial departments and customs) or other related departments (invoicing department, creditors and debtors). Then, after review, return any inconsistent raw data to the original business units or branches and ask them to state the reasons and correct it.

3) Inquire related departments (such as accounting firms, commodity price 
department and etc.) for some data required in vouchers such as goods price and asset price and etc. Through the internet to confirm the inventory values and the values of the assets and materials. Then, leave them to the inventory management or fixed asset management systems.

4) The host computer may, based on the raw data unnecessary to be reviewed and the consistent raw data after being reviewed or the corrective raw data, prepare vouchers for keeping accounts automatically according to the financial software requirements. Then, based on the vouchers for keeping accounts, it may automatically register the summary general ledger and summary subsidiary ledger and ledger ledger and subsidiary ledger and send the ledger to appropriate departments or branches.

5) The host computer may prepare a variety of accounting statements according a variety of accounting books automatically and send them to the appropriate users through the internet.

6) Through the internet, the corporate releases all relevant information which shall be disclosed to the public investors as required by relevant management departments (such as China Securities Regulatory Commission (CSRC)).

7) The corporate managements release relevant information or work orders to the lower-level departments or branches through the internet.

8) The grassroots units (such as business units or branches) and accounting information users (such as debtors, creditors, government functional departments and investors and etc.) get access to their needed accounting information through internet.

Accounting data security refers to there are no omissions, illegal copying, adding or deformation during the generation, transmission, receiving, storage and processing process of the accounting data and information. To ensure data security, on one hand, relevant laws, policies and regulations shall be followed, on the other hand, corporate managements shall formulate effective management systems. Meanwhile, strict monitoring and management means are also required.

\section{Conclusions}

This paper mainly discussed the concepts, functions of internal control of computerized accounting system and its characteristics and analyzed in detail the general control and application control of computerized accounting information system. Based on this, it analyzed the computerized accounting system running in internet environment and its internal control flows, characteristics and ways. This is to help the corporate to increase risk awareness when setting up computerized accounting system and carefully establishes internal control system, as well as, practically implement appropriate control measures to maximize the accounting information quality.

\section{References}

[1]Yang Baogang. Accounting Information system. Higher Education Press, 2007:17-98

[2]Liu Zongliu, Chen Hanwen. Corporate Internal Control Theories, Practices and Cases. China Financial and Economic Press, 2009:32-148

[3] Li Fengmin. Internal Control and Risk Prevention. Economic Science Press, 2008:29-103

[4] America. Charles T Hengrey, Mitchell A Robinson, Trans. Wang Huacheng, Dai Deming. Accounting. China People University Press. 2008:36-97

[5] Mao Yi. Computerized Accounting. Capital University of Economics \& Business Press, 2009:19-82 